Article

SILVA, K.S. ${ }^{*}$

TABALDI, L.A. ${ }^{2}$

ROSSATO, L.V. ${ }^{2}$

CAVICHIOLI, B.M. ${ }^{3}$

BASÍLIO, V.B. ${ }^{4}$

MACHADO, S.L.O. ${ }^{2}$

* Corresponding author:

<keli_agro@yahoo.com.br>

Received: September 9, 2017

Approved: January 26, 2018

Planta Daninha 2019; v37:e019185130

Copyright: This is an open-access article distributed under the terms of the Creative Commons Attribution License, which permits unrestricted use, distribution, and reproduction in any medium, provided that the original author and source are credited.

\section{Contents of Pigments and Activity of Antioxidant Enzymes in Rice Plants Pre-Treated with Sodium NitRopRUSSIDE AND EXPOSED TO ClOMAZONE}

\section{Conteúdo de Pigmentos e Atividade de Enzimas Antioxidantes em Plantas de Arroz Pré-Tratadas com Nitroprussiato de Sódio e Expostas a Clomazone}

\begin{abstract}
The pre-treatment of rice seeds with sodium nitroprusside (SNP) was used to investigate the effect of exogenous nitric oxide on the pigment content and the activity of antioxidant enzymes during the inhibition of the 2-C-methyl-D-erythritol 4-phosphate (MEP) pathway by the herbicide clomazone. The seeds were soaked in SNP solution $(200 \mathrm{mM})$ for one and 10 hours and sprayed with clomazone, at postseeding and at the needle-point, with 612 (experiment 1) and 1,224 g a.i. ha ${ }^{-1}$ (experiment 2). The control of both factors received distilled water. Carotenoids, chlorophylls $a, b$ and total, superoxide dismutase (SOD), guaiacol peroxidase (POD) and the correlation between the variables were evaluated in the shoot of the plants. When compared to the control (no SNP), the imbibition for one hour increased carotenoid and total chlorophyll content by 24 and 54\%, respectively, in experiment 1 , where clomazone was applied in post-seeding. In the absence of the herbicide, the values were 37 and 59\% higher. The SOD and POD activity, respectively, was increased by 48 and $51 \%$, when the seeds were soaked for 10 hours and exposed to $612 \mathrm{~g}$ a.i. ha ${ }^{-1}$ of clomazone in post-seeding application. In a similar condition, in experiment 2 , there were no changes in enzyme activity. Seed pretreatment with SNP increases the carotenoid and chlorophyll contents in rice plants, even with the inhibition of the MEP pathway by clomazone. The behavior of the SOD and POD activity indicates that other mechanisms besides the increase in the photosynthetic pigment contents are involved in the detoxification of the reactive oxygen species induced by the mode of action of clomazone.
\end{abstract}

Keywords: chlorophyll, carotenoids, Oryza sativa, superoxide dismutase, guaiacol peroxidase.

RESUMO - O pré-tratamento das sementes de arroz com nitroprussiato de sódio (SNP) foi usado para investigar o efeito do óxido nítrico exógeno sobre o conteúdo de pigmentos e a atividade de enzimas antioxidantes durante a inibição da rota 2$C$-metil-D-eritritol 4-fosfato (MEP), pelo herbicida clomazone. As sementes foram embebidas em solução de SNP (200 mM) por uma e 10 horas e pulverizadas com clomazone, em pós-semeadura e no ponto de agulha, com 612 (experimento 1) e $1.224 \mathrm{~g}$ i.a. ha-1 (experimento 2). As testemunhas de ambos os fatores receberam água destilada. Carotenoides, clorofilas a, b e total, superóxido dismutase (SOD), guaiacol peroxidase (POD) e a correlação entre as variáveis foram avaliados na parte aérea das plantas. Quando comparados à testemunha (sem SNP), a embebição por uma hora aumentou o conteúdo de carotenoides e clorofila total em 24 e 54\%, respectivamente, no experimento 1, onde clomazone foi aplicado em pós-semeadura. Na ausência do herbicida, os valores foram 37 e 59\% superiores. A atividade da

1 WeedOut - Mais conhecimento, menos plantas daninhas, Formigueiro-RS, Brasil; ${ }^{2}$ Universidade Federal de Santa Maria, Santa Maria-RS, Brasil; ${ }^{3}$ Bayer Crop Science, Santa Maria-RS, Brasil; ${ }^{4}$ Universidade Federal de Pelotas, Pelotas-RS, Brasil. 
SOD e POD foi aumentada em 48 e 51\%, respectivamente, quando as sementes foram embebidas por 10 horas e expostas a $612 \mathrm{~g}$ i.a. $\mathrm{ha}^{-1}$ de clomazone em pós-semeadura. Em condição similar, no experimento 2, não houve alterações na atividade das enzimas. O pré-tratamento das sementes com SNP aumenta os níveis de carotenoides e clorofilas nas plantas de arroz, mesmo com a inibição da rota MEP pelo clomazone. O comportamento da atividade da SOD e POD indica que outros mecanismos, além do aumento nos níveis dos pigmentos fotossintéticos, estão envolvidos na detoxificação das espécies reativas de oxigênio, induzidas pelo modo de ação do clomazone.

Palavras-chave: clorofila, carotenoides, Oryza sativa, superóxido dismutase, guaiacol peroxidase.

\section{INTRODUCTION}

Clomazone (2-(2-chlorobenzyl)-4,4-dimethyl-isoxazolidine-3,5-dione) is a pre-herbicide widely used to control weeds in irrigated rice crops, and it may be applied in pre-emergence or during initial post-emergence, in association with other herbicides (Andres et al., 2013). However, at high concentrations, even in tolerant cultures, toxic effects of clomazone on the plastid enzyme 1-deoxy-D-xylulose 5-phosphate synthase (DXS) have been observed, consequently, affecting the biosynthesis of photosynthetic pigments, such as carotenoids and chlorophyll $a$ and $b$ (Darwish et al., 2013).

Converted by plants into the active metabolite 5-cetoclomazone (Dayan and Watson, 2011), clomazone also interferes in the photosynthesis process, since it blocks the formation of chloroplastic isoprenoids, on the 2-C-methyl-D-erythritol 4-phosphate (MEP) route, including tocopherol and electron carriers (Eisenreich et al., 2004). In addition, the inhibition of the synthesis of carotenoids, which protect the plants, when dissipating the excess of energy generated during the photosynthesis (Jahns and Holzwarth, 2012), leads to an uncontrolled production of reactive oxygen species (ROSs), which may react with macromolecules on membranes, such as lipids, proteins and DNA (Souza et al., 2012), causing the death of the plants. Thus, clomazone has been used to study the implications of suppressing the MEP route (Kuzuyama and Seto, 2012), photosynthesis (Darwish et al., 2013) and the protective effect of nitric oxide (NO) on the oxidative stress (Silva et al., 2016).

Associated to several vegetable physiology and biochemistry events, NO is related to the increase of the antioxidant capacity of the plants to mitigate the effects of the oxidative damage (Farooq et al., 2009). It acts by directly detoxifying ROSs or by regulating the action of antioxidant enzymes, such as dismutase superoxide (DSO), guaiacol peroxidase (POD), catalase (CAT) and glutathione reductase (GR), implying the existence of an interface between NO and ROSs (Qian et al., 2009). Its exogenous supply, through donors, such as sodium nitroprusside (SNP), is indicated for reducing the deleterious effects resulting from the oxidative stress caused by herbicides (Sood et al., 2012). However, the antioxidant mechanisms involved are not yet completely known (He et al., 2014).

The soaking of the seeds in SNP solution and later exposition to the stress inducer has been a recurring strategy to evaluate these mechanisms in seedlings (Farooq et al., 2009; Hayat et al., 2014; He et al., 2014). However, the concentration of the NO donor, the time of exposure of the seeds to the solution and the interval between the exposure and the treatment, as well as the nature of the stressor, may interfere in the results. Ederli et al. (2009), when studying the NO release kinetics from SNP, verified an initial peak over the three first hours, followed by a reduced but continuous release. Also, the water absorption curve of the seeds depends on the species and the genotype. In rice seeds, a fast absorption occurs over the first 10 to 12 hours of phase I of germination (He and Yang, 2013).

Thus, this study was conducted to evaluate the effect of nitric oxide on the pigment content and the action of superoxide dismutase and guaiacol peroxidase antioxidant enzymes, concomitantly to the suppression of the MEP route, through the treatment of seeds from the irrigated rice cultivar Puitá INTA CL, with different periods of soaking in sodium nitroprusside solution, and exposure to different doses of the clomazone herbicide, applied in post-sowing and during the needle-point stage. 


\section{MATERIAL AND METHODS}

The experiments, sown in November, at the growth station $2014 / 15$, were conducted in an area that is adequate for irrigated rice crops in Formigueiro (latitude of 30 4'13.6"S and longitude of 533'ㅇ.06"W), Rio Grande do Sul, Brazil, in a soil classified as Hapludalf Planosol, belonging to the mapping unit Vacacaí (Embrapa, 2006), which presented the following physical-chemical characteristics: clay $=35 \% ; \mathrm{pH}_{\text {water }}(1: 1)=5.2 ; \mathrm{P}=5.3 \mathrm{mg} \mathrm{dm}^{-3} ; \mathrm{K}=88.0 \mathrm{mg} \mathrm{dm}^{-3} ; \mathrm{Ca}=$ $6.9 \mathrm{cmol}_{\mathrm{c}} \mathrm{dm}^{-3} ; \mathrm{Mg}=4.0 \mathrm{cmol}_{\mathrm{c}} \mathrm{dm}^{-3}$ and $\mathrm{MO}=1.8 \%$.

In both experiments, organized in completely randomized blocks, the treatments were organized in a $3 \times 3$ factorial, with four replications. Factor A consists in the exposure or not of the seeds to sodium nitroprusside (SNP), by soaking the nitric oxide donor in a solution $(200 \mu \mathrm{M})$ for (i) one hour, (ii) 10 hours and (iii) control. Factor $\mathrm{C}$ comprehended the time in which the herbicide treatment was sprayed, through the application of clomazone during (i) post-sowing, (ii) at needle-point and (iii) the control, without herbicide. On experiments 1 and 2, the equivalent to doses of 612 and 1,224 g a.i. ha ${ }^{-1}$ of clomazone was used, respectively, representing two different levels of stress to the plants, caused by the inhibition of the MEP route.

The preparation of the SNP aqueous solution occurred immediately before the use, and the seeds from the Puitá INTA CL cultivar were soaked in the dark. For the control, the seeds were soaked only in distilled water. The beginning of the soaking periods was adjusted so that all treatments were concomitantly removed from the solution and immediately sown, in line, at a density of 350 seeds $\mathrm{m}^{-2}$, in humid soil. The experimental units, with $6 \mathrm{~m}^{2}$, were sprayed with the respective doses of clomazone, 24 hours after sowing (post-sowing) or immediately before the emergence of the seedlings (needle-point), five days after sowing. The control received only distilled water. For all pulverizations, the $\mathrm{CO}_{2}$ pressurized backpack sprayer (3 bar) was used, equipped with 11002 spraying nozzles and solution volume equivalent to $200 \mathrm{~L} \mathrm{ha}^{-1}$, under the climatic conditions established for greater efficiency.

During the three-leaf stage $\left(\mathrm{V}_{3}\right)$ (Counce et al., 2000), 21 days after sowing and after enough time for the herbicide, allied to solar radiation, to express potential damage, the shoot of the plants was collected on the central area of the plots $\left(2 \mathrm{~m}^{2}\right)$ and washed in distilled water, and the leaves, without the sheath, were immediately frozen in liquid nitrogen and send to cryopreservation $\left(-80^{\circ} \mathrm{C}\right)$, at the Plant Physiology Laboratory, were all biochemical analyses were conducted in duplicates.

For the enzymatic activity and protein content, a supernatant of $0.5 \mathrm{~g}$ of leaf tissue was used, homogenized in $3 \mathrm{~mL}$ of potassium phosphate buffer $(0.05 \mathrm{M}, \mathrm{pH} 7.8)$, EDTA $1 \mathrm{mM}$ and Triton $\mathrm{X}-100(1 \%)$ and centrifuged at $13,000 \mathrm{~g}$ for 20 minutes at $4{ }^{\circ} \mathrm{C}$ (Zhu et al., 2004). The protein contents followed the Bradford method (1976), using bovine albumin.

The dismutase superoxide activity was measured according to Giannopolitis and Ries (1977). A SOD unit was defined as the amount of the enzyme that inhibits the nitroblue tetrazolium (NBT) by the photoreduction of 50\% (Beauchamp and Fridovich, 1971). The action of the guaiacol peroxidase enzyme was measured according to Zeraik et al. (2008), in which $50 \mu \mathrm{L}$ of vegetable extract were added to the reaction mixture containing $1.0 \mathrm{~mL}$ of potassium phosphate buffer (100 mM, pH 6.5), $1.0 \mathrm{~mL}$ of guaiacol $(15 \mathrm{mM})$ and $1.0 \mathrm{~mL}$ of $\mathrm{H}_{2} \mathrm{O}_{2}$. The guaiacol oxidation into tetraguaiacol was measured by the absorbance increase in $470 \mathrm{~nm}$.

The chlorophylls $(a+b)$ and carotenoids were extracted following the Hiscox and Israeslstam method (1979) and estimated using Lichtenthaler formula (1987), in which $0.05 \mathrm{~g}$ of leaf tissue was incubated $\left(65^{\circ} \mathrm{C}\right)$ in dimethyl sulfoxide (DMSO) for 31 minutes, until the tissues were completely white. The solution absorption was measured at 663 and $645 \mathrm{~nm}$ for chlorophylls and $470 \mathrm{~nm}$ for carotenoids.

The data collected in each experiment was analyzed as to the normality and homogeneity of the variances, transformed when necessary and subjected to ANOVA $(p \leq 0.05)$, with the averages separated by the Scott-Knott test $(p \leq 0.05)$, according to the significance of the interaction among the factors. The relationship between the photosynthesis pigments and the enzymatic activity was verified through Pearson's correlation coefficient $(r)$ (Brussab and Morettin, 1986). 


\section{RESULTS AND DISCUSSION}

Evaluated 21 days after sowing, the exposure of the rice plants to the clomazone herbicide, at a dose of $612 \mathrm{~g}$ a.i. ha-1 (experiment 1), caused no significant changes to the carotenoid levels, while the dose of 1,224 g a.i. ha ${ }^{-1}$ (experiment 2), when applied at the needle-point and compared to the control, without herbicide and without SNP treatment, reduced the pigment content in $17 \%$, with the highest level of injury caused to the plant at the highest dose (Table 1). The soaking of the seeds with sodium nitroprusside (SNP) increased the carotenoid content, however, the effect depended on the interaction among the factors. On plants that were not exposed to clomazone (control), the treatment of the seeds with SNP for 1 and 10 hours increased the carotenoid content in up to 34 and $28 \%$, respectively, indicating a relationship between the nitric oxide and the pigment synthesis.

Table 1 - Levels of carotenoids, chlorophyll $a$, chlorophyll $b$ and total chlorophyll ( $\mathrm{mg} \mathrm{g}^{-1}$ of fresh weight) in rice plants from the Puitá INTA CL cultivar pre-treated with $200 \mu \mathrm{M}$ of sodium nitroprusside for 1 or 10 hours and exposed to 612 and $1,224 \mathrm{~g}$ a.i. ha-1 ${ }^{-1}$ of clomazone during post-sowing and at needlepoint

\begin{tabular}{|c|c|c|c|}
\hline \multirow{2}{*}{ Application time } & \multicolumn{3}{|c|}{ Sodium nitroprusside } \\
\hline & Control & $200 \mu \mathrm{M}$ for 1 hour & $200 \mu \mathrm{M}$ for 10 hours \\
\hline \multicolumn{4}{|c|}{ Carotenoids } \\
\hline \multicolumn{4}{|c|}{$612 \mathrm{~g}$ a.i. ha ${ }^{-1}$ de clomazone } \\
\hline Post-sowing & $0.313 \pm(0.022) \mathrm{b}^{\mathrm{ns}}$ & $0.388 \pm(0.015) \mathrm{aAB}$ & $0.368 \pm(0.019) \mathrm{aAB}$ \\
\hline Needle-point & $0.328 \pm(0.015) b$ & $0.373 \pm(0.025) \mathrm{aB}$ & $0.345 \pm(0.017) \mathrm{abB}$ \\
\hline Control & $0.308 \pm(0.010) b$ & $0.413 \pm(0.010) \mathrm{aA}$ & $0.393 \pm(0.015) \mathrm{aA}$ \\
\hline \multicolumn{4}{|c|}{$1,224 \mathrm{~g}$ a.i. $\mathrm{ha}^{-1}$ of clomazone } \\
\hline Post-sowing & $0.295 \pm(0.019) \mathrm{abA}$ & $0.275 \pm(0.010) \mathrm{bB}$ & $0.323 \pm(0.015) \mathrm{aB}$ \\
\hline Needle-point & $0.255 \pm(0.013) \mathrm{bB}$ & $0.270 \pm(0.020) \mathrm{bB}$ & $0.325 \pm(0.024) \mathrm{aB}$ \\
\hline Control & $0.308 \pm(0.010) \mathrm{bA}$ & $0.413 \pm(0.010) \mathrm{aA}$ & $0.393 \pm(0.015) \mathrm{aA}$ \\
\hline \multicolumn{4}{|c|}{ Chlorophyll $a$} \\
\hline \multicolumn{4}{|c|}{$1,224 \mathrm{~g}$ a.i. $\mathrm{ha}^{-1}$ of clomazone } \\
\hline Post-sowing & $0.843 \pm(0.162) \mathrm{A}^{\mathrm{ns}}$ & $0.742 \pm(0.075) \quad \mathrm{B}$ & $0.886 \pm(0.103) \quad \mathrm{B}$ \\
\hline Needle-point & $0.664 \pm(0.096) \mathrm{bB}$ & $0.724 \pm(0.074) \mathrm{bB}$ & $0.888 \pm(0.134) \mathrm{aB}$ \\
\hline Control & $0.848 \pm(0.131) \mathrm{bA}$ & $1.216 \pm(0.096) \mathrm{aA}$ & $1.138 \pm(0.149) \mathrm{aA}$ \\
\hline \multicolumn{4}{|c|}{ Chlorophyll $b$} \\
\hline \multicolumn{4}{|c|}{$612 \mathrm{~g}$ a.i ha ${ }^{-1}$ of clomazone } \\
\hline Post-sowing & $0.368 \pm(0.063) \mathrm{c}^{\mathrm{ns}}$ & $0.725 \pm(0.052) \mathrm{aA}$ & $0.496 \pm(0.037) b^{\mathrm{ns}}$ \\
\hline Needle-point & $0.376 \pm(0.019)^{\mathrm{ns}}$ & $0.473 \pm(0.106) \mathrm{B}$ & $0.410 \pm(0.019)$ \\
\hline Control & $0.371 \pm(0.061) \mathrm{b}$ & $0.630 \pm(0.087) \mathrm{aA}$ & $0.552 \pm(0.152) \mathrm{a}$ \\
\hline \multicolumn{4}{|c|}{ 1,224 g a.i. ha ${ }^{-1}$ of clomazone } \\
\hline Post-sowing & $0.393 \pm(0.096)^{\mathrm{ns}}$ & $0.429 \pm(0.088) \quad \mathrm{B}$ & $0.382 \pm(0.054) \mathrm{B}$ \\
\hline Needle-point & $0.284 \pm(0.034)^{\mathrm{ns}}$ & $0.307 \pm(0.048) \quad \mathrm{B}$ & $0.406 \pm(0.099) \mathrm{B}$ \\
\hline Control & $0.371 \pm(0.061) \mathrm{B}$ & $0.630 \pm(0.087) \mathrm{aA}$ & $0.552 \pm(0.152) \mathrm{aA}$ \\
\hline \multicolumn{4}{|c|}{ Total chlorophyll } \\
\hline \multicolumn{4}{|c|}{$612 \mathrm{~g}$ a.i. ha $\mathrm{ha}^{-1}$ of clomazone } \\
\hline Post-sowing & $2.058 \pm(0.147) \mathrm{c}^{\mathrm{ns}}$ & $3.170 \pm(0.210) \mathrm{aA}$ & $2.603 \pm(0.121) b A$ \\
\hline Needle-point & $2.068 \pm(0.051) \mathrm{c}$ & $2.590 \pm(0.137) \mathrm{aB}$ & $2.313 \pm(0.175) \mathrm{bB}$ \\
\hline Control & $2.050 \pm(0.138) \mathrm{c}$ & $3.265 \pm(0.158) \mathrm{aA}$ & $2.723 \pm(0.141) b A$ \\
\hline \multicolumn{4}{|c|}{$1.224 \mathrm{~g}$ a.i. ha $^{-1}$ of clomazone } \\
\hline Post-sowing & $2.163 \pm(0.154) \mathrm{aA}$ & $1.803 \pm(0.198) b B$ & $2.110 \pm(0.087) \mathrm{aB}$ \\
\hline Needle-point & $1.668 \pm(0.278) \mathrm{bB}$ & $1.695 \pm(0.185) \mathrm{bB}$ & $2.220 \pm(0.101) \mathrm{aB}$ \\
\hline Control & $2.050 \pm(0.138) \mathrm{cA}$ & $3.265 \pm(0.158) \mathrm{aA}$ & $2.723 \pm(0.141) b A$ \\
\hline
\end{tabular}

Averages followed by the same lowercase letter in the same row do not differ regarding the seed treatment, and those with the same uppercase letter in the column do not differ regarding the application time of clomazone, according to the Scott-Knott test ( $\mathrm{p} \leq 0.05$ ) ${ }^{n s}$ Non-significant. The values in parentheses represent the standard deviation of the average. 
On experiment 1 , the levels of chlorophyll $a$ increased due to the treatment of the seeds with SNP (Figure 1A). On experiment 2, an interaction of the factors occurred, and there was no significant difference to the levels of chlorophyll $a$ when the herbicide was applied post-sowing. On the other hand, at needle-point, the levels were increased in 33.7\% on plants exposed to SNP for 10 hours (Table 1), following the behavior presented by carotenoids with that same treatment, which may indicate the preservation of chlorophyll $a$ in photosystem II, due to the nophotochemical dissipation by the accessory pigments (Song et al., 2013).
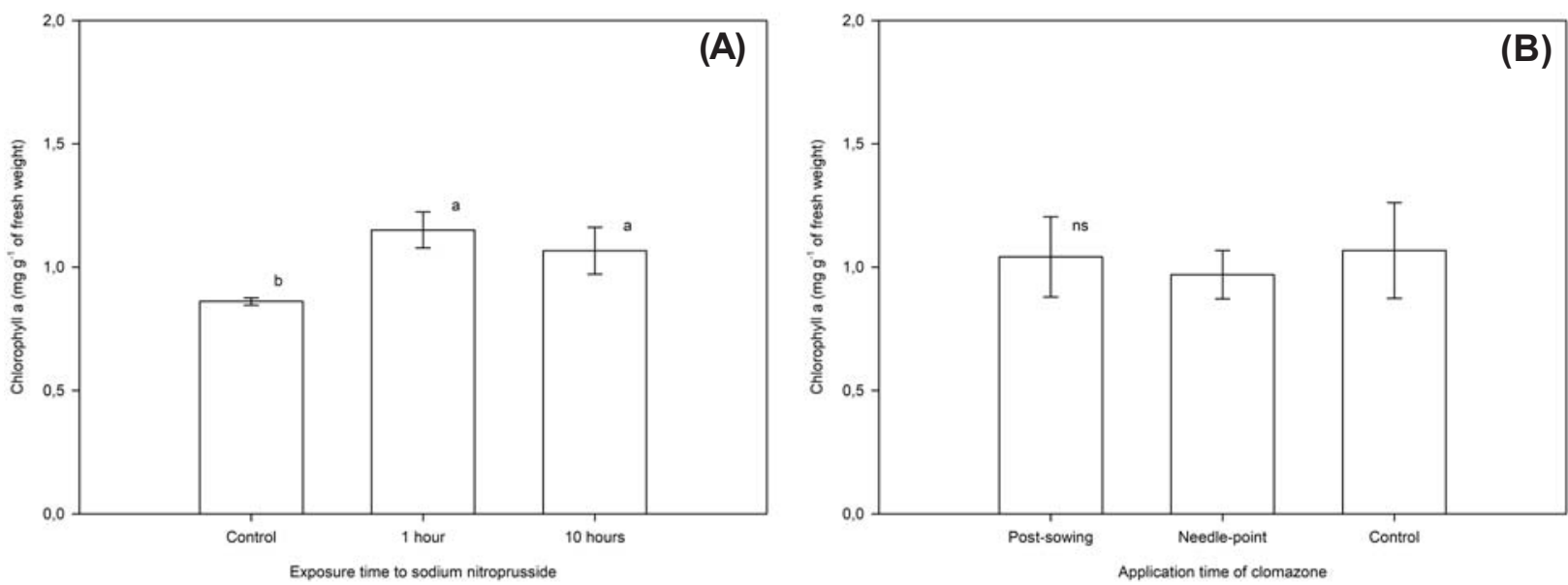

Averages followed by the same letter do not differ according to the Scott-Knott test $(\mathrm{p} \leq 0.05)$, while vertical bars represent the standard deviation of the average.

Figure 1 - Chlorophyll $a$ levels ( $\mathrm{mg} \mathrm{g}^{-1}$ of fresh weight) in rice plants from the Puitá INTA CL cultivar pre-treated with $200 \mu \mathrm{M}$ of sodium nitroprusside for (A) 1 and 10 hours and exposed to $612 \mathrm{~g}$ a.i. ha ${ }^{-1}$ of clomazone in (B) post-sowing and at needle-point.

The levels of chlorophyll $b$ and total were equally increased by the treatment of the seeds with SNP on both experiments, exceeding the contents shown by the control, with no treatment. The reduction of the chlorophyll contents on plants treated with 1,224 $\mathrm{g}$ a.i. ha ${ }^{-1}$ of clomazone, at needle-point and with the absence of SNP, is a result of the mechanism of action of the herbicide. In addition, as essential pigments on photosynthetic organisms, the role of carotenoids is to dissipate the excess of chlorophyll energy during photosynthesis, avoiding the formation of triplet chlorophyll and singlet oxygen, which induce the oxidative stress. In the absence of these pigments, the tissues are visually chlorotic, due to the possible destruction of chlorophylls and, consequently, of the photosystems (Foyer et al., 1994).

In agreement with these findings, Darwish et al. (2013) found a reduction on the contents of photosynthetic pigments in tobacco plants as the clomazone concentration increased, while Kana et al. (2004) found that the herbicide reduced the formation of pigment-protein compounds on the thylakoid membranes. Injuries resulting from increasing doses of clomazone were also verified by Andres et al. (2013) in different irrigated rice cultivars, with later recovery of the plant. In most cases, there was no significant difference as to the time interval between the soaking of the seeds with SNP and the exposure to the herbicide, represented by the application times, which may indicate the action of NO even after the donor is exhausted. However, when it occurs, the highest toxicity promoted by the pulverization of clomazone at needle-point may be attributed to the reduced time interval between the exposure to the herbicide and the collection for evaluation, showing the shortest recovery period of the plants in relation to the positioning at post-sowing.

The soaking of the seeds with SNP increased the chlorophyll and carotenoid contents in relation to the control, without the application of clomazone, indicating, under these circumstances, an increase on the synthesis of these pigments. According to Graziano and Lamattina (2005), NO is able to maintain the homeostasis of iron and benefit its internal transportation, thus, promoting the biosynthesis of chlorophyll and the development of chloroplasts. The results by Riquelme et al. (2017) suggest that nitric oxide is involved in a cascade of luminous 
signals that measures the accumulation of chlorophylls and proteins synthetized during the development of the organelle. Also, the inhibition of the expression of the 1-deoxy-D-xylulose 5phosphate reductoisomerase (DXR) enzyme by the NO synthase inhibitor $N \omega$-nitro-L-arginine methyl ester (L-NAME) and by the nitric oxide scavenger 2-(4-Carboxyphenyl)-4,4,5,5tetramethylimidazoline-1-oxyl-3-oxide (c-PTIO), contributes with the evidences that both mevalonate (MVE) and MEP routes are induced by SNP (Du et al., 2015). In Catharanthus roseus, the treatment with SNP increased the concentration of terpenoid indole alkaloids produced by the MEP route (Zhu et al., 2015).

The treatment in which the seeds were soaked with $200 \mu \mathrm{M}$ of SNP for one hour and $612 \mathrm{~g}$ a.i. $\mathrm{ha}^{-1}$ of clomazone was applied, during post-sowing, showed an increase on the contents of all pigments, concomitantly to the reduction on the action of the superoxide dismutase (Table 2) and guaiacol peroxidase (Table 3) enzymes, indicating a possible dissipation of the excess of photosynthetic energy by the pigments produced, reducing the formation of free radicals that promote the peroxidation of lipids and damages to the membranes (Chen et al., 2009). This increase on the pigment content may have been enough to avoid the formation of reactive oxygen species, without the need to activate the antioxidant enzymes.

Also, in experiment 1, when the seeds were treated with SNP for 10 hours and the herbicide was sprayed during post-sowing, the action of the SOD and POD enzymes increased in 59 and $61 \%$, respectively, together with the reduction of the antioxidant pigment contents, indicating another possible detoxification route, or even an cytotoxic effect caused by the greater exposure to NO, whose effects on plants have been associated to its concentration (Hayat et al., 2014). The activation of the superoxide dismutase and other enzymes, such as ascorbate peroxidase and catalase also occurred when leaves of Vicia faba were treated with SNP and exposed to UVB

Table 2 - Activity of superoxide dismutase ( $\mathrm{U} \mathrm{mg}^{-1}$ of protein) in rice plants from the Puitá INTA CL cultivar pre-treated with $200 \mu \mathrm{M}$ of sodium nitroprusside for 1 and 10 hours and exposed to $612 \mathrm{~g}$ a.i. ha ${ }^{-1}$ of clomazone during post-sowing and at needlepoint

\begin{tabular}{|l|c|c|c|}
\hline \multirow{2}{*}{ Application time } & \multicolumn{3}{|c|}{ Sodium nitroprusside } \\
\cline { 2 - 4 } & Control & $200 \mu \mathrm{M}$ for 1 hour & $200 \mu \mathrm{M}$ for 10 hours \\
\hline Post-sowing & $14.06 \pm(0.688) \mathrm{b}^{\mathrm{ns}}$ & $11.89 \pm(1.211) \mathrm{cB}$ & $20.80 \pm(2.19) \mathrm{aA}$ \\
\hline Needle-point & $14.45 \pm(0.999)^{\mathrm{ns}}$ & $13.58 \pm(1.261) \mathrm{A}$ & $13.16 \pm(0.39) \mathrm{B}$ \\
\hline Control & $13.06 \pm(0.768)^{\mathrm{ns}}$ & $11.84 \pm(1.748) \mathrm{B}$ & $12.08 \pm(1.47) \mathrm{B}$ \\
\hline
\end{tabular}

Averages followed by the same lowercase letter in the same row do not differ regarding the seed treatment, and those with the same uppercase letter in the column do not differ regarding the application time of clomazone, according to the Scott-Knott test ( $\mathrm{p} \leq 0.05$ ) ns Non-significant. The values in parentheses represent the standard deviation of the average.

Table 3 - Activity of guaiacol peroxidase ( $\mathrm{U} \mathrm{mg}^{-1}$ of protein) in rice plants from the Puitá INTA CL cultivar pre-treated with $200 \mu \mathrm{M}$ of sodium nitroprusside for 1 and 10 hours and exposed to 612 and 1,224 g a.i. ha ${ }^{-1}$ of clomazone during post-sowing and at needle-point

\begin{tabular}{|l|c|c|c|}
\hline \multirow{2}{*}{ Application time } & \multicolumn{3}{|c|}{ Sodium nitroprusside } \\
\cline { 2 - 4 } & Control & $200 \mu \mathrm{M}$ for 1 hour & $200 \mu \mathrm{M}$ for $10 \mathrm{hours}$ \\
\hline & \multicolumn{3}{|c|}{$612 \mathrm{~g} \mathrm{a} . \mathrm{i} . \mathrm{ha}^{-1}$ of clomazone } \\
\hline Post-sowing & $14.18 \pm(1.455) \mathrm{bB}$ & $11.11 \pm(1.054) \mathrm{cA}$ & $21.39 \pm(1.539) \mathrm{aA}$ \\
\hline Needle-point & $16.18 \pm(1.222) \mathrm{aA}$ & $12.68 \pm(1.483) \mathrm{bA}$ & $11.74 \pm(2.140) \mathrm{bB}$ \\
\hline Control & $13.30 \pm(1.588) \mathrm{aB}$ & $7.56 \pm(0.641) \mathrm{bB}$ & $7.29 \pm(0.849) \mathrm{bC}$ \\
\hline \multicolumn{3}{|c|}{$1,224 \mathrm{~g}$ a.i. ha $\mathrm{h}^{-1}$ of clomazone } \\
\hline Post-sowing & $13.42 \pm(1.088) \mathrm{bB}$ & $16.90 \pm(1.070) \mathrm{aA}$ & $12.36 \pm(0.888) \mathrm{bB}$ \\
\hline Needle-point & $16.02 \pm(2.390) \mathrm{A} \mathrm{ns}^{\mathrm{ns}}$ & $15.94 \pm(0.923) \mathrm{A}$ & $16.50 \pm(0.908) \mathrm{A}$ \\
\hline Control & $13.10 \pm(1.588) \mathrm{aB}$ & $7.56 \pm(0.641) \mathrm{bB}$ & $7.29 \pm(0.849) \mathrm{bC}$ \\
\hline
\end{tabular}

Averages followed by the same lowercase letter in the same row do not differ regarding the seed treatment, and those with the same uppercase letter in the column do not differ regarding the application time of clomazone, according to the Scott-Knott test ( $\mathrm{p} \leq 0.05$ ) ${ }^{n s}$ Non-significant. The values in parentheses represent the standard deviation of the average. 
radiation (Shi et al., 2005). The concentration and characteristics of the species, the environment and the elicitor stress are indicated as conditions for the mechanisms of action of NO (Du et al., 2015).

On experiment 2, the application of 1,224 g a.i. ha ${ }^{-1}$ of clomazone increased the SOD activity, regardless of the application time of the herbicide (Figure 2A), while the treatment of the seeds with SNP did not produce significant effects (Figure 2B). For soybean, the addition of sodium nitroprusside promoted the retention photosynthetic pigments and slowed down the peroxidation of lipids on cotyledons (Jasid et al., 2009), as well as for beans, where the pre-treatment of the leaves with SNP mitigated injuries to the photosynthetic apparatus, induced by UVB radiation (Shi et al., 2005).
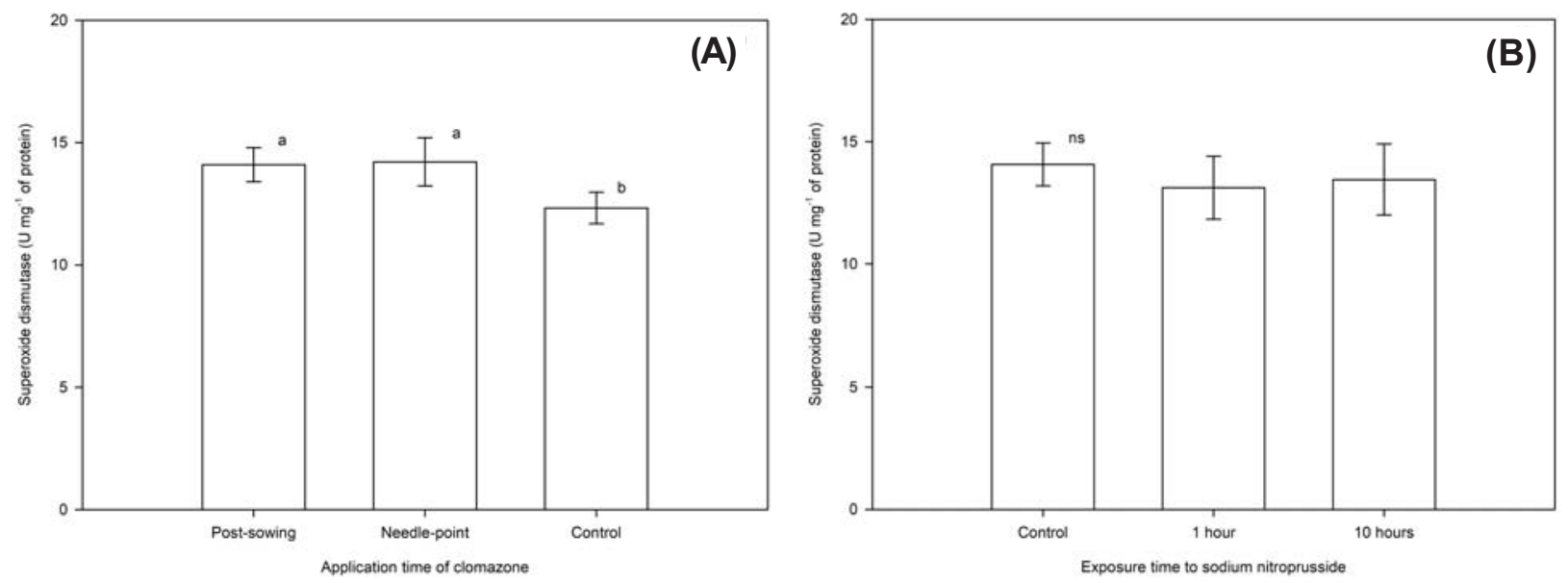

Averages followed by the same letter do not differ according to the Scott-Knott test ( $\mathrm{p} \leq 0.05)$, while vertical bars represent the standard deviation of the average.

Figure 2 - Activity of superoxide dismutase in rice plants from the Puitá INTA CL cultivar pre-treated with $200 \mu \mathrm{M}$ of sodium nitroprusside for (A) 1 and 10 hours and exposed to $1,224 \mathrm{~g}$ a.i. ha ${ }^{-1}$ of clomazone in (B) post-sowing and at needle-point.

The strong positive correlation between the photosynthetic pigments (Table 4) on both experiments confirms the importance of carotenoids to the preservation of chlorophylls during the photoinhibition caused by the herbicide clomazone. On experiment 1, the increase on the pigment content did not influence the SOD activity, while it slightly reduced the POD activity. On experiment 2 , the activity of both enzymes was negatively correlated to the levels of carotenoids and chlorophylls. The SOD and POD enzymes are positively correlated on both experiments. Considering that the biochemistry of the photosynthesis is at all times under the control of several enzymes and metabolic intermediates in a highly coordinate fashion (Choudhury and Behera, 2001), it is possible that other factors, related to the metabolism of the reactive oxygen and nitrogen species, have influenced the action of the enzymes on this study.

Under controlled conditions, Li et al. (2011) verified positive effects on the production of alkaloids on the roots of Catharanthus roseus, treated with SNP, 30 days after the exposure to the NO donor. Farooq et al. (2009) verified that seeds soaked in SNP solution produced adult rice plants that were more tolerant to stress due to water deficit, and that NO is able of promoting long-term effects, preparing the plants for a better performance when subjected to stressful episodes (Conrath, 2011). Thus, evaluations conducted after the exhaustion of the donor may confirm the involvement of NO in inducing the signalization of events that control the cellular redox status (Grob et al., 2013), as observed on this study.

The soaking of the seeds in sodium nitroprusside solution increases the levels of carotenoids and chlorophylls on rice plants, even with the inhibition of the MEP route by the clomazone herbicide. Reduction, increase or absence of significant effects on the SOD and POD activity indicate that other mechanisms, in addition to the increase on the levels of photosynthetic pigments, are involved in the detoxification of the reactive oxygen species induced by the mode of action of clomazone. 
Table 4 - Pearson's correlation coefficients between the photosynthetic pigment content and the action of superoxide dismutase and guaiacol peroxidase enzymes in rice plants from the Puitá INTA CL cultivar pre-treated with $200 \mu \mathrm{M}$ of sodium nitroprusside for 1 and 10 hours and exposed to 662 and 1,224 g a.i. ha ${ }^{-1}$ of clomazone during post-sowing and at needle-point

\begin{tabular}{|c|c|c|c|c|c|}
\hline Variable & Chl a & Chl b & Chl Total & SOD & POD \\
\hline \multicolumn{6}{|c|}{$662 \mathrm{~g}$ a.i. ha $^{-1}$ of clomazone } \\
\hline Car & $0.867 *$ & $0.789 *$ & $0.899 *$ & -0.150 & $-0.414 *$ \\
\hline Chl a & & $0.756^{*}$ & $0.815^{*}$ & -0.041 & -0.257 \\
\hline Chl b & & & $0.883^{*}$ & -0.264 & $-0.363^{*}$ \\
\hline Chl total & & & & -0.222 & $-0.429 *$ \\
\hline SOD & & & & & $0.820 *$ \\
\hline \multicolumn{6}{|c|}{1,224 g a.i. ha ${ }^{-1}$ of clomazone } \\
\hline Car & $0.885^{*}$ & $0.809 *$ & $0.928^{*}$ & $-0.471 *$ & $-0.809 *$ \\
\hline Chl a & & $0.859 *$ & $0.899 *$ & $-0.508^{*}$ & $-0.741 *$ \\
\hline Chl b & & & $0.816^{*}$ & $-0.444 *$ & $-0.607 *$ \\
\hline Chl total & & & & $-0.489 *$ & $-0.808^{*}$ \\
\hline SOD & & & & & $0.551 *$ \\
\hline
\end{tabular}

* Significant at $\mathrm{P} \leq 0.05$. Carotenoids (Car), Chlorophyll $a(\mathrm{Chl} a)$, Chlorophyll $b$ (Chl b), Total chlorophyll (Chl total), Superoxide dismutase (SOD) and guaiacol peroxidase (POD).

\section{ACKNOWLEDGEMENTS}

We thank the coordination of Coordenação de Aperfeiçoamento de Pessoal de Nivel Superior (CAPES) for the scholarship granted to the first author.

\section{REFERENCES}

Andres A, Concenço G, Theisen G, Vidotto F, Ferrero A. Selectivity and weed control efficacy of pre- and post-emergence applications of clomazone in Southern Brazil. Crop Prot. 2013;53:108-8.

Beauchamp CO, Fridovich I. Superoxide dismutase. Improved assays and an assay applicable to acrylamide gel. Anal Biochem. $1971 ; 44: 276-87$.

Bradford MM. A rapid and sensitive method for the quantitation of microgram quantities of protein utilizing the principle of protein-dye binding. Anal Biochem. 1976;72:248-54.

Brussab WO, Morettin PA. Estatística básica. São Paulo: Atual; 1986.

Chen J, Shiyab S, Han FX, Monts DL, Waggoner CA, Yang Z, Su Y. Bioaccumulation and physiological effects of Mercury in Pteris vittata and Nephrolepis exaltata. Ecotoxicology. 2009;18(1):110-21.

Choudhury NK, Behera RK. Photoinhibition of photosynthesis: role of carotenoids in photoprotection of chloroplast constituents. Photosynthetica. 2001;39:481-8.

Conrath U. Molecular aspects of defence priming. Trends Plant Sci. 2011;16:524-31.

Counce P, Keisling TC, Mitchell AJ. Uniform, objective, and adaptive system for expressing rice development. Crop Sci. 2000;40:436-43.

Darwish M, Lopez-Lauri F, Sallanon H. Study of photosynthesis process in the presence of low concentrations of clomazone herbicide in tobacco (Nicotiana tabacum). J Stress Physiol Biochem. 2013;9:229-45.

Dayan FE, Watson SB. Plant cell membrane as a marker for light dependent and light-independent herbicide mechanisms of action. Pestic Biochem Physiol. 2011;101:182-90.

Du X, Zhang C, Guo W, Jin W, Liang Z, Yan X, et al. Nitric oxide plays a central role in water stress-induced tanshinone production in Salvia miltiorrhiza hairy roots. Molecules. 2015;20(5):7574-85. 
Ederli L, Reale L, Madeo L, Ferranti F, Gehring C, Fornaciari M, et al. NO release by nitric oxide donors in vitro and in planta. Plant Physiol Biochem. 2009;47:42-8.

Eisenreich W, Bacher A, Arigoni D, Rohdich F. Biosynthesis of isoprenoids via the non-mevalonate pathway. Cell Mol Life Sci. 2004;61(12):1401-26.

Empresa Brasileira de Pesquisa Agropecuária - Embrapa. Centro Nacional de Pesquisa de Solos. Sistema Brasileiro de Classificação dos Solos. Brasília, DF: Embrapa-SPI, 2006. 412p.

Farooq M, Basra SMA, Wahid A, Rehman H. Exogenously applied nitric oxide enhances the drought tolerance in fine grain aromatic rice (Oryza sativa L.). J Agron Crop Sci. 2009;195(4):254-61.

Foyer CH, Lelandais M, Kunert KJ. Photooxidative stress in plants. Physiol Plant. 1994;92(4):696-717.

Giannopolitis CN, Ries SK. Superoxide dismutase I. Occurrence in higher plants. Plant Physiol. 1977;59:309-14.

Graziano M, Lamattina L. Nitric oxide and iron in plants: an emerging and converging story. Trends Plant Sci. 2005;10:4-8.

Grob F, Durner J, Gaupels F. Nitric oxide, antioxidants and prooxidants in plant defence responses. Front Plant Sci. 2013;4:1-15.

Hayat S, Yadav S, Alyemeni MN, Ahmad A. Effect of sodium nitroprusside on the germination and antioxidant activities of tomato (Lycopersicon esculentum Mill ). Bulg J Agric Sci. 2014;20(1):140-4.

He D, Yang P. Proteomics of rice seed germination. Front Plant Sci. 2013;4:1-9.

He J, Ren Y, Chen X, Chen H. Protective roles of nitric oxide on seed germination and seedling growth of rice (Oryza sativa L.) under cadmium stress. Ecotoxicol Environ Saf. 2014;108:114-9.

Hiscox JD, Israelstam GF. A method for the extraction of chlorophyll from leaf tissue without maceration. Can J Bot. $1979 ; 57: 1132-4$.

Jahns P, Holzwarth AR. The role of the xanthophyll cycle and of lutein in photoprotection of photosystem II. Biochim Biophys Acta. 2012;1817:182-93.

Jasid S, Galatro A, Villordo JJ, Puntarulo S, Simontacchi M. Role of nitric oxide in soybean cotyledon senescence. Plant Sci. 2009;176(5):662-8.

Kana R, Špundová M, Ilýì P, Lazár D, Klem K,Tomek P, et al. Effect of herbicide clomazone on photosynthetic processes in primary barley (Hordeum vulgare L.) leaves. Pestic Biochem Physiol. 2004;78(3):161-70.

Kuzuyama T, Seto H. Two distinct pathways for essential metabolic precursors for isoprenoid biosynthesis. Proc Jpn Acad, Ser B, Phys Biol Sci. 2012;88:41-52.

Li M, Peebles CA, Shanks JV, San KY. Effect of sodium nitroprusside on growth and terpenoid indole alkaloid production in Catharanthus roseus hairy root cultures. Biotechnol Prog. 2011;27(3):625-30.

Lichtenthaler H.K. Chlorophylls and carotenoids: pigments of photosynthetic biomembranes. Meth Enzymol. 1987;148:350-82.

Qian H, Chen W, Li J, Wang J, Zhou Z, Liu W, et al. The effect of exogenous nitric oxide on alleviating herbicide damage in Chlorella vulgaris. Aquat Toxicol. 2009;92(4):250-7.

Riquelme A, Alvarez P, Pinto M. Exogenous applications of nitric oxide affect the chlorophyll content and the expression of ELIPs-like protein in grapevine ( Vitis vinifera L.). Acta Hortic. 2017;1157:309-14.

Shi S, Wang G, Wang Y, Zhang L, Zhang L. Protective effect of nitric oxide against oxidative stress under ultraviolet-B radiation. Nitric Oxide. 2005;13(1):1-9.

Silva KS, Urban LJK, Balbinot A, Gnocato FS, Kruse ND, Marchesan E, et al. Electrolyte leakage and the protective effect of nitric oxide on leaves of flooded rice exposed to herbicides. Planta Daninha. 2016;34(4):777-85.

Song L, Yue L, Zhao H, Hou M. Protection effect of nitric oxide on photosynthesis in rice under heat stress. Acta Physiol Plant. 2013;35(12):3323-33. 
Sood A, Kalra C, Pabbi S, Uniyal PL. Differential responses of hydrogen peroxide, lipid peroxidation and antioxidant enzymes in Azolla microphylla exposed to paraquat and nitric oxide. Biologia. 2012;67(6):1119-28.

Souza RC, Ferreira DTRG, Vitorino HS, Barbosa GVS, Endres L, Ferreira VM. Oxidative stress in Emilia coccinea (Asteraceae) caused by a mixture of Clomazone + Ametryn. Int Inter Res J Plant Sci. 2012;3(5):80-7.

Zeraik AE, Souza FS, Fatibello-Filho O, Leite OD. Desenvolvimento de um spot test para o monitoramento da atividade da peroxidase em um procedimento de purificação. Quím Nova. 2008;31(4):731-4.

Zhu J, Wang M, Wen W, Yu R. Biosynthesis and regulation of terpenoid indole alkaloids in Catharanthus roseus. Pharmacogn Rev. 2015;9(17):24-8.

Zhu Z, Wei G, Li J, Qian Q, Yu J. Silicon alleviates salt stress and increases antioxidant enzymes activity in leaves of salt stressed cucumber (Cucumis sativus L.). Plant Sci. 2004;167(3):527-33. 